\title{
Analysis of Genetic Diversity among Selected Grasspea (Lathyrus sativus L.) Genotypes Using RAPD Markers
}

\author{
Durga P. Barik ${ }^{\mathrm{a}}$, Laxmikanta Acharya ${ }^{\mathrm{b}}$, Arup K. Mukherjee ${ }^{\mathrm{b}}$, \\ and Pradeep K. Chand ${ }^{\mathrm{a}, *}$ \\ a Plant Cell, Tissue \& Organ Culture Facility, Post-Graduate Department of Botany, \\ Utkal University, Vani Vihar, Bhubaneswar-751004, Orissa, India. \\ E-mail: pkchanduubot@rediffmail.com \\ b DNA Fingerprinting Laboratory, Division of Plant Biotechnology, Regional Plant Resource \\ Center (RPRC), Nayapalli, Bhubaneswar-751015, Orissa, India \\ * Author for correspondence and reprint requests \\ Z. Naturforsch. 62c, 869-874 (2007); received March 13/May 21, 2007
}

Randomly amplified polymorphic DNA (RAPD) technique was applied to assess the genetic variability among five selected genotypes of grasspea. Out of 30 random decamer primers tested for the present investigation 20 showed reproducible DNA amplification. A total of 257 loci were amplified of which 159 were polymorphic including 57 genotype-specific unique bands. Amplicons had molecular weights ranging from $3.0 \mathrm{~kb}$ to $0.1 \mathrm{~kb}$. Majority amplicons were shared by most of the genotypes which indicated a very narrow genetic gap between them. The dendrogram constructed on the basis of RAPD data showed two clusters. The local genotype collected from Nayagarh was grouped along with IC-120451 and IC120453 , sharing a common node at an $82 \%$ similarity level. The other genotypes, IC-120478 and IC-120487, were located in the second clade having a common node at $84 \%$ similarity level. The investigation showed that though all the genotypes of grasspea were of apparently similar morphology there exists polymorphism at the molecular level, which can be exploited in breeding programmes aimed at crop improvement.

Key words: Genetic Diversity, Grasspea, RAPD

\section{Introduction}

Grasspea (Lathyrus sativus L., Fabaceae) is the most important grain legume cultivated as one of the cheapest sources of dietary lysine-rich protein for the people of low income food deficit countries (LIFDCs) and also as fodder for farm animals. It is an important pulse crop in several tropical and sub-tropical countries and is well adapted to adverse agricultural conditions such as flooding, drought, salinity, low soil fertility and pathogeninfested soil (Zambre et al., 2002). Unfortunately, efforts to exploit the potential of this grain legume are limited because of the presence of a neurotoxic amino acid, $\beta$ - $N$-oxalyl-L- $\alpha, \beta$-diaminopropionic acid (ODAP/BOAA), in the grain protein, which causes neurolathyrism in humans on prolonged consumption. The plant species, being sexually propagated, often displays morphological variations.

To study the genetic diversity and species phylogeny of the genus Lathyrus morphological characters, cytology and enzyme electrophoresis were examined by Ben Brahim et al. (1900) and Yunus and Jackson (1991). Recently, molecular techniques have been developed for studying the genetic variability in grasspea using RFLP and PCR-based markers such as RAPD (randomly amplified polymorphic DNA), SSR and AFLP (Chtourou-Ghorbel et al., 2001, 2002). Chattopadhyay et al. (2005) studied the genetic diversity among the genotypes of mungbean (Vigna radiata) using RAPD and ISSR markers. Molecular markers like RAPD, RFLP, ISSR and AFLP are stable, reliable and not influenced by the environment and thus being used now-a-days for the assessment of the genetic diversity and establishing the genomic relationship among different plant taxa (Acharya et al., 2005). The present work was undertaken for the characterization of five elite genotypes of Lathyrus using RAPD markers so as to reveal the genetic relationship among them.

\section{Materials and Methods}

\section{Plant material}

For the present study, seeds of four different genotypes (IC-120451, IC-120453, IC-120478, IC- 
Table I. Morphological characters of different genotypes of Lathyrus sativus.

\begin{tabular}{lllll}
\hline Genotype & Plant habit & Leaf shape/size & $\begin{array}{l}\text { Flower colour and } \\
\text { size }\end{array}$ & $\begin{array}{l}\text { Seed colour and } \\
\text { shape/size }\end{array}$ \\
\hline Nayagarh Local & Normal height & $\begin{array}{l}\text { Narrow, thin, } \\
\text { normal length }\end{array}$ & Blue, medium size & $\begin{array}{l}\text { Brownish white with } \\
\text { dots, not completely } \\
\text { rounded }\end{array}$ \\
IC-120451 & $\begin{array}{l}\text { Normal height with } \\
\text { less branching }\end{array}$ & $\begin{array}{l}\text { Narrow with } \\
\text { distinct ribs, short } \\
\text { length }\end{array}$ & Blue, small size & $\begin{array}{l}\text { Slight reddish, normal } \\
\text { size }\end{array}$ \\
IC-120453 & $\begin{array}{l}\text { Normal height } \\
\text { Bushy with profuse } \\
\text { branching }\end{array}$ & $\begin{array}{l}\text { Wrinkle shape } \\
\text { Narrow (thin) }\end{array}$ & Blue, small size & Brownish white \\
IC-120487 & Branching with profuse & $\begin{array}{l}\text { Wider (thick with } \\
\text { prominent ribs) }\end{array}$ & $\begin{array}{l}\text { Blue with ribs, } \\
\text { distinct larger size } \\
\text { than other four } \\
\text { genotypes }\end{array}$ & $\begin{array}{l}\text { Brownish, larger than } \\
\text { all four genotypes }\end{array}$ \\
\hline
\end{tabular}

120487) and one local genotype (Nayagarh Local) of Lathyrus sativus L. were collected from NBPGR, New Delhi and Pulse Research Station at Nayagarh, Orissa, respectively. Plants raised from these genotypes had some morphological variations with respect to plant habit, leaf shape/ size, colour and size of the flower and seed (Table I).

\section{Genomic DNA isolation}

DNA was isolated from young and fresh leaves using the CTAB method described by Saghai-Maroof et al. (1984). RNA was removed by giving RNase treatment (@60 $\mu \mathrm{g}$ for $1 \mathrm{ml}$ of crude DNA solution at $37^{\circ} \mathrm{C}$ ) followed by two washes of phenol/chloroform/isoamyl alcohol (25:24:1 v/v) and subsequently two washes with chloroform/isoamyl alcohol (24:1 v/v). After centrifugation the upper aqueous phase was separated, 1/10 volume of $3 \mathrm{M}$ sodium acetate ( $\mathrm{pH} 4.8)$ was added and DNA was precipitated with 2.5 volumes of pre-chilled absolute ethanol. DNA was dried and dissolved in $\mathrm{T}_{10} \mathrm{E}_{1}$ buffer (10 mM Tris hydroxy amino methanechloride, $1 \mathrm{~mm}$ EDTA, pH 8.0). Quantification was made by running the dissolved DNA in $0.8 \%$ agarose gel alongside uncut $\lambda$ DNA of known concentration. The DNA was diluted to $25 \mathrm{ng} / \mu \mathrm{l}$ for RAPD analysis.

For RAPD analysis, PCR amplification of $25 \mathrm{ng}$ genomic DNA was carried out using 30 standard decamer oligonucleotide primers, of which 20 primers were able to generate reproducible amplification. So they were selected for the present RAPD analysis; OPA02, OPA03, OPA05, OPA10,
OPA16, OPA18, OPD02, OPD03, OPD05, OPD07, OPD08, OPD16, OPD18, OPD20, OPN02, OPN04, OPN05, OPN08, OPN16 and OPN20 (Operon Tech., Alameda, CA, USA). The RAPD analysis was performed as per the standard methods (Williams et al., 1990). Each amplification reaction mixture of $25 \mu \mathrm{l}$ contained $20 \mathrm{ng}$ of template DNA, $2.5 \mu \mathrm{l}$ of $10 \mathrm{X}$ assay buffer (100 mM Tris- $\mathrm{HCl}, \mathrm{pH} 8.3,0.5 \mathrm{M} \mathrm{KCl}$, and $0.01 \%$ gelatin), $1.5 \mathrm{~mm} \mathrm{MgCl}_{2}, 200 \mu \mathrm{M}$ of each dNTP, $20 \mathrm{ng}$ of primer and $0.5 \mathrm{U}$ Taq DNA polymerase (Bangalore Genei Pvt. Ltd., Bangalore, India). The amplification was carried out in a thermal cycler (Applied Biosystems, CA, USA). The first cycle consisted of denaturation of template DNA at $94^{\circ} \mathrm{C}$ for $5 \mathrm{~min}$, primer annealing at $37^{\circ} \mathrm{C}$ for $1 \mathrm{~min}$ and primer extension at $72{ }^{\circ} \mathrm{C}$ for $2 \mathrm{~min}$. In the subsequent 42 cycles the period of denaturation was reduced to 1 min while the primer annealing and primer extension time were maintained the same as in the first cycle. The last cycle consisted of only primer extension at $72{ }^{\circ} \mathrm{C}$ for $7 \mathrm{~min}$. PCR products were separated on $1.5 \%$ agarose gel containing ethidium bromide solution (@0.5 $\mu \mathrm{g}$ / $\mathrm{ml}$ of gel solution). The size of the amplicons was determined using size standards (100 bp ladder plus or DNA ladder mix, MBI Fermentas, Lithuania). DNA fragments were visualized under UV light and the images stored and processed using the Gel Documentation System (Bio-Rad, USA).

\section{Data analysis}

The bands amplified from RAPD were scored as ' 1 ' and ' 0 ' for the presence and absence of a 
band, respectively. All the bands whether monomorphic or polymorphic were used for similarity calculation in order to avoid over-estimation of distance (Gherardi et al., 1998). Jaccard's coefficients of similarity (Jaccard, 1908) were calculated and a dendrogram based on the similarity coefficients was obtained through the un-weighted pair group method using arithmetic averages (UPGMA) (Sneath and Sokal, 1973) and SHAN clustering. All the analyses were done by using the computer package NTSYS-PC-2.02e (Rohlf, 1997).

\section{Resolving power $(R p)$}

Resolving power of the RAPD was calculated as per Prevost and Wilkinson (1999) according to: $\mathrm{Rp}=\Sigma \mathrm{IB}$, where IB (band informativeness) $=1-$ $[2 \times(0.5-\mathrm{P})]$ and $\mathrm{P}$ is the proportion of the 5 varieties containing the band.

\section{$R A P D$ primer index (RPI)}

The RPI was calculated from the polymorphic index (PIC) which was calculated according to: PIC $=1-\Sigma \mathrm{P}_{\mathrm{i}}^{2}$, where $\mathrm{P}_{\mathrm{i}}$ is the band frequency of the allele (Smith et al., 1997). In case of RAPDs and ISSRs, PIC was considered to be $1-\mathrm{p}^{2}-\mathrm{q}^{2}$, where $\mathrm{p}$ is the band frequency and $\mathrm{q}$ is no band frequency (Ghislain et al., 1995). PIC value was then used to calculate the RPI. RPI is the sum of the PIC of all the markers amplified by the same primer.

\section{Principal coordinate analysis (PCA)}

PCA was performed based on the RAPD data for all the primers (Semagn et al., 2000). PCA was used to retrieve information about the clustering pattern of the analyzed population.

\section{Results}

Out of 30 decamer oligonucleotide primers evaluated for the present investigation 20 were found to be successful in DNA amplification generating reproducible distinct bands for RAPD (Fig. 1). A total of 257 loci were amplified in the RAPD analysis of which 98 bands were monomorphic while 159 bands were polymorphic including 57 unique genotype-specific bands (Table II). The amplicons were amplified in the range of 100 to 3000 base pairs. The RAPD banding pattern of the five genotypes of Lathyrus sativus is presented in Fig. 1. The maximum of 114 loci was amplified in case of the genotype Nayagarh Local and the minimum (73) in case of IC-120453. The highest number of 27 unique bands was detected for IC-120478 and 10 , the lowest, for IC-120453. The highest number of 102 polymorphic bands was generated for IC120453 and the lowest (61) for Nayagarh Local (data not shown). The maximum (31) and minimum (6) number of bands were amplified with the primer OPN16 and OPA03 or OPN05, respectively (Table II). Among the primers used, OPA16 generated the maximum number of polymorphic bands but the highest number of unique bands was noted with the primer OPN05. Maximum similarity was seen among the species with the primer OPA10. While the highest number of unique loci got amplified with OPN05, the lowest number of genotype-specific loci was found with the primer OPA16, i.e. 1. Among the RAPD primers used, the resolving power ranged from 3.0 for OPA02

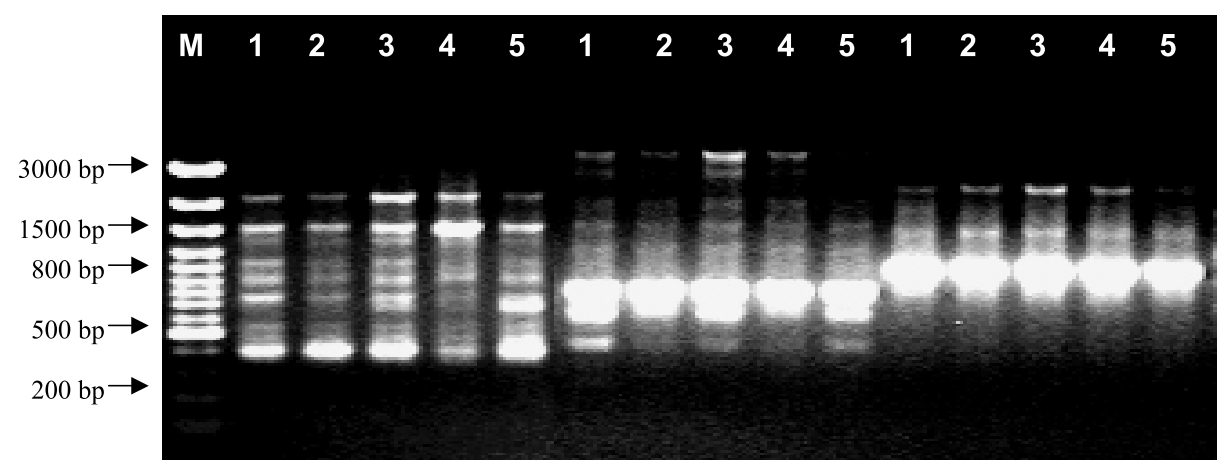

Fig. 1. RAPD banding pattern in Lathyrus sativus genotypes. 1, Nayagarh Local; 2, IC-120451; 3, IC-120453; 4, IC120478; 5, IC-120487; M, 100 bp ladder plus; primers: OPA02 for the 1st set (1-5), OPA18 for the 2nd set (1-5), OPD02 for the $3 \mathrm{rd}$ set $(1-5)$. 
Table II. Details of the banding pattern in different genotypes of Lathyrus sativus.

\begin{tabular}{|c|c|c|c|c|c|c|}
\hline Primer & Nucleotide sequence & $\begin{array}{l}\text { Total } \\
\text { bands }\end{array}$ & $\begin{array}{l}\text { Polymorphic } \\
\text { bands }\end{array}$ & $\begin{array}{l}\text { Monomorphic } \\
\text { bands }\end{array}$ & $\begin{array}{l}\text { Resolving } \\
\text { power }\end{array}$ & $\begin{array}{l}\text { RAPD primer } \\
\text { index }\end{array}$ \\
\hline OPA02 & 5'TGCCGAGCTG3' & 12 & 11 & 01 & 03.0 & 12.8 \\
\hline OPA03 & 5'AGTCAGCCAC3' & 06 & 02 & 04 & 10.0 & 02.0 \\
\hline OPA05 & 5'AATCGGGCTG3' & 11 & 11 & 00 & 03.0 & 10.8 \\
\hline OPA10 & 5'GTGATCGCAG3 & 22 & 08 & 14 & 35.6 & 08.4 \\
\hline OPA16 & $5^{\prime} \mathrm{AGCCAGCGAA3^{ \prime }}$ & 29 & 20 & 09 & 40.4 & 17.6 \\
\hline OPA18 & 5'AGGTGACCGT3' & 11 & 03 & 08 & 18.8 & 03.2 \\
\hline OPD02 & 5'GGACCCAACC3' & 08 & 03 & 05 & 12.8 & 03.2 \\
\hline OPD03 & 5'GTCGCCGTCA3' & 08 & 03 & 05 & 12.8 & 03.2 \\
\hline OPD05 & 5'TGAGCGGACA3' & 17 & 12 & 05 & 24.0 & 10.0 \\
\hline OPD07 & 5'TTGGCACGGG3' & 13 & 08 & 05 & 20.0 & 06.0 \\
\hline OPD08 & 5'GTGTGCCCCA3' & 10 & 10 & 00 & 03.0 & 07.6 \\
\hline OPD16 & 5'GTGTGCCCCA3' & 11 & 10 & 01 & 03.0 & 08.4 \\
\hline OPD18 & $5^{\prime}$ GAGAGCCAAC $3^{\prime}$ & 15 & 12 & 03 & 18.0 & 12.0 \\
\hline OPD20 & $5^{\prime}$ ACCCGGTCAC3' & 10 & 07 & 03 & 07.0 & 11.2 \\
\hline OPN02 & $5^{\prime} \mathrm{ACCAGGGGCA3^{ \prime }}$ & 11 & 04 & 07 & 19.2 & 02.8 \\
\hline OPN04 & 5'GACCGACCCA3' & 07 & 02 & 05 & 12.0 & 02.0 \\
\hline OPN05 & 5'ACTGAACGCC 3' & 06 & 03 & 03 & 09.6 & 02.4 \\
\hline OPN08 & 5'ACCTCAGCTC3' & 09 & 07 & 02 & 10.0 & 04.0 \\
\hline OPN16 & 5'AAGCGACCTG3' & 31 & 19 & 12 & 44.8 & 17.2 \\
\hline OPN20 & 5'GAGACGCACA3' & 10 & 04 & 06 & 14.4 & 05.6 \\
\hline Total & & 257 & 159 & 98 & & \\
\hline
\end{tabular}

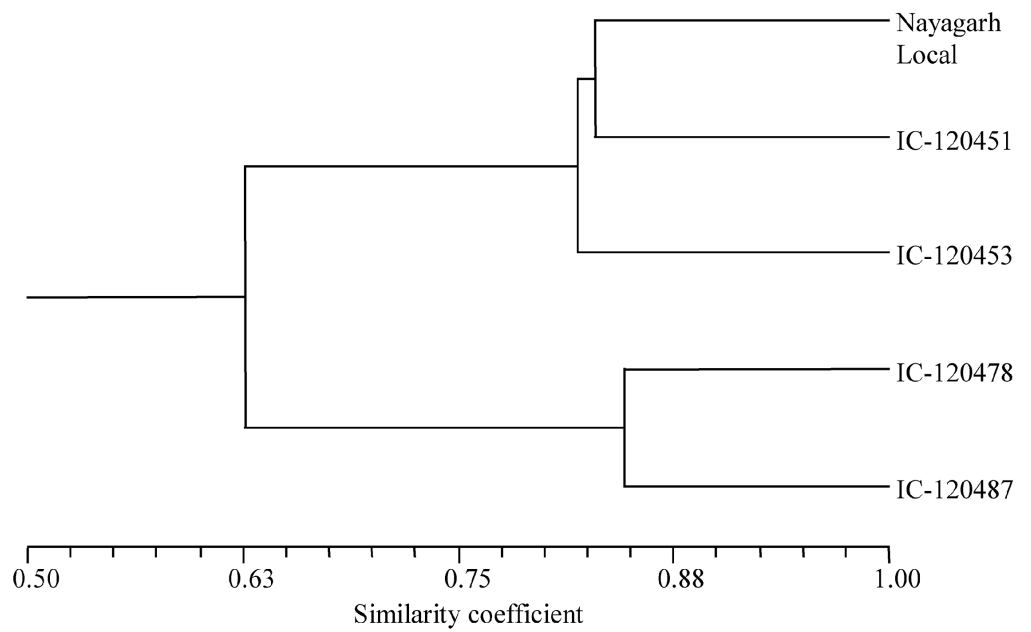

Fig. 2. Dendrogram constructed on the basis of RAPD data in genotypes of grasspea.

and OPA05 to 44.8 for OPN16 (Table. II). Among a total of five elite genotypes studied, the highest similarity was observed between IC-120478 and IC-120487 (84.62\%), which shared a common node at the similarity coefficient of 0.84 (Fig. 2). The local genotype collected from Nayagarh was grouped along with IC-120451 and IC-120453 sharing a common node at the similarity coefficient of 0.82. The Nayagarh Local genotype showed maximum similarity $(82.98 \%)$ with IC-
120451 and the latter with IC-120453 at $82.61 \%$ (Table III). The same trend was evident from the principal coordinate analysis (data not shown).

\section{Discussion}

All the five genotypes were segregated into two clusters. In the first cluster the genotypes Nayagarh Local, IC-120451 and IC-120453 were grouped together. Our result is supported by some mor- 


\begin{tabular}{|c|c|c|c|c|c|}
\hline & 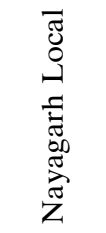 & 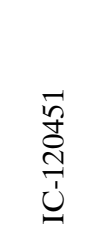 & $\frac{\stackrel{n}{n}}{\stackrel{\bigcup}{S}}$ & 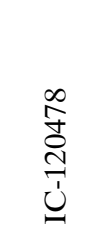 & 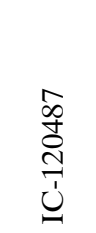 \\
\hline Nayagarh Local & 1.0000 & & & & \\
\hline IC-120451 & 0.8298 & 1.0000 & & & \\
\hline IC-120453 & 0.8125 & 0.8261 & 1.0000 & & \\
\hline IC- 120478 & 0.6200 & 0.5918 & 0.6989 & 1.0000 & \\
\hline IC-120487 & 0.5842 & 0.6211 & 0.6421 & 0.8462 & 1.0000 \\
\hline
\end{tabular}

Table III. Jaccard's coefficients of similarity between different genotypes using RAPD markers.

phological features common to these cultivars, both being of normal height with less branching and bearing small and blue flowers. In the second cluster the remaining two genotypes IC-120478 and IC-120487 were grouped. These two genotypes have some common morphological characters such as a bushy and profusely branched habit, blue flowers with red dots and ribs being the largest in IC-120487. Interestingly, in the present investigation it was observed that the morphological similarities in these genotypes had an identical reflection at molecular level.

Chtourou-Ghorbel et al. $(2001,2002)$ were the first to apply RAPD analysis to five different species of Lathyrus (L. sativus, L. cicera, L. ochrus, $L$. sylvestris and $L$. latifolius). The RAPDs obtained were sufficient to distinguish between two accessions of a species and to separate these accessions by clustering them according to species. A high genetic similarity between the populations of L. sylvestris and L. latifolius was established. PCRbased markers were also used to detect and assess the genetic variation in a selected core collection of Lathyrus sativus L. (Polignano et al., 2003). A study was performed on the 44 entries using 36 pair-wise RAPD primer combinations (DPRAPD, double primer RAPD) and 5 AFLP primer combinations. A dendrogram of genetic similarity was obtained from polymorphic bands scored in both molecular analyses, comparing the results to detect the efficiency of the two classes of markers to reveal intraspecific polymorphism in the species (Polignano et al., 2003).

Similar types of responses were observed in other related legumes like mungbean (Vigna radiata), for which RAPD and ISSR markers were employed to estimate the genetic diversity among selected germplasm comprising varieties, landraces and wild accessions (Chattopadhyay et al., 2005). Though polymorphism among the varieties was moderate; it was high $(83 \%)$ when the whole set of germplasm was considered. Lakhanpaul et al. (2000) also reported low to moderate polymorphism while analyzing 32 Indian mungbean cultivars using 21 RAPD primers and observed four clusters in dendrograms. The largest intraspecific variation in Vigna radiata var. sublobata was detected through RAPD analysis (Kaga et al., 1996). Inheritance and linkage relationship between eight morphological and RAPD markers studied in Lens culinaris revealed that the traits such as leaf, stem and pod pigmentation were linked to each other (Hoque et al., 2002).

The results of the present investigation using RAPD markers have successfully revealed an informative DNA polymorphism among grasspea genotypes which could be integrated into markerassisted selection and breeding programs aiming at genetic improvement of this nutritionally important crop species. 
Acharya L., Mukherjee A. K., Panda P. C., and Das P. (2005), Molecular characterization of five medicinally important species of Typhonium (Araceae) through random amplified polymorphic DNA (RAPD). Z. Naturforsch 60c, 600-604.

Ben Brahim N., Boussaid M., and Marrakchi M. (1990), Analyze dela biologie florale chez trios especes annuelles de Lathyrus. Ann. Inst. Nat. Rech. Agr. Tunisie 63, 15-21.

Chattopadhyay K., Nasim Ali Md., Sarkar H. K., Mandal N., and Bhattacharya S. (2005), Diversity analysis by RAPD and ISSR markers among the selected mungbean [Vigna radiata (L.) Wilczek] genotypes. Indian J. Genet. Plant Breed. 65, 173-175.

Chtourou-Ghorbel N., Lauga B., Combes D., and Marrakchi M. (2001), Genetic diversity studies in the genus Lathyrus using AFLP and RAPD markers. Lathyrus Lathyrism News Lett. 2, 62-68.

Chtourou-Ghorbel N., Lauga B., Ben Brahim N., Combes D., and Marrakchi M. (2002), Genetic variation analysis in the genus Lathyrus using RAPD markers. Genet. Res. Crop Evol. 49, 365-372.

Gherardi M., Mangin B., Goffinet B., Bonnet B. D., and Huguet T. (1998), A method to measure genetic distance between allogamous populations of alfalfa (Medicago sativa) using RAPD molecular markers. Theor. Appl. Genet. 96, 406-412.

Ghislain M., Zhang D., Fazardo D., Huamann Z., and Hismans R. H. (1995), Marker-assisted sampling of the cultivated Andean potato Solanum fureja collection using RAPD markers. Genet. Res. Crop Evol. 46, $547-555$.

Hoque M. E., Mishra S. K., and Sarker A. (2002), Inheritance and linkage relationship between morphological and RAPD markers in lentil (Lens culinaris Medik.). Indian J. Genet. Plant Breed. 62, 5-10.

Jaccard P. (1908), Nouvelles recherches sur la distribution florale. Bull. Soc. Vaud. Sci. Nat. 44, 223-270.

Kaga A., Tomooka N., Egawa Y., Hosaka K., and Kamijima O. (1996), Species relationships in the subgenus Ceratotropis (genus Vigna) as revealed by RAPD analysis. Euphytica 88, 17-24.

Lakhanpaul S., Chadha S., and Bhat K. V. (2000), Random amplified polymorphic DNA (RAPD) analysis in Indian mungbean (Vigna radiata (L.) Wilczek) cultivars. Genetica 109, 227-234.

Polignano G. B., Lotti C., Alba V., De Giovanni C., Dell'Orco C., and Ricciardi C. (2003), Comparative analysis of RAPD and AFLP polymorphisms in a core collection of grasspea (Lathyrus sativus L. ). Proceedings of the XLVII Italian Society of Agricultural Genetics (SIGA) Annual Congress, Verona, Italy, pp. 24-27.

Prevost A. and Wilkinson M. J. (1999), A new system of comparing PCR primers applied to ISSR fingerprinting of potato cultivars. Theor. Appl. Genet. 98, 661668.

Rohlf F. J. (1997), NTSYS-PC. Numerical taxonomy and multivariate analysis system, version 2.02e. Exeter Software, New York.

Saghai-Maroof M. A., Soliman K. M., Jerenson R. A., and Allard R. W. (1984), Ribosomal DNA spacer length polymorphism in barley: Mendelian inheritance, chromosomal location and population dynamics. Proc. Natl. Acad. Sci. USA 81, 8014-8018.

Semagn K., Bjornstad A., Stedje B., and Bekell E. (2000), Comparison of multivariate methods for the analysis of genetic resources and adaptation in Phytolacca dodecandra using RAPD. Theor. Appl. Genet. 101, 1145-1154.

Smith J. S. C., Chin E. C. L., Shu H., Smith O. S., Wall S. J., Senior M. L., Mitchell S. E., Kresovich S., and Ziegle J. (1997), An evaluation of the utility of SSR loci as molecular markers in maize (Zea mays L.): Comparison of data from RFLPs and pedigree. Theor. Appl. Genet. 95, 163-173.

Sneath P. H. A. and Sokal R. (1973), Numerical Taxonomy. Freeman, San Francisco, California.

Williams J. G. K., Kubelik A. R., Livak K. J., Rafalski J. A., and Tingey S. V. (1990), DNA polymorphisms amplified by arbitrary primers are useful as genetic markers. Nucleic Acids Res. 18, 6531-6535.

Yunus A. G. and Jackson M. T. (1991), The gene pools of the grasspea (Lathyrus sativus L. ). Plant Breeding 106, 319-328.

Zambre M., Chowdhury B., Kuo Y., Van Montagu M., Angenon G., and Lambein F. (2002), Prolific regeneration of fertile plants from green nodular callus induced from meristematic tissues in Lathyrus sativus L. (grasspea). Plant Sci. 163, 1107-1112. 